Supporting Information

\title{
Engineered Nanoconfinement Accelerating Spontaneous Manganese-Catalyzed Degradation of Organic Contaminants
}

Shuo Zhang, Tayler Hedtke, Li Wang, Xiaoxiong Wang, Tianchi Cao, Menachem Elimelech, Jae-Hong Kim*

Department of Chemical and Environmental Engineering, Yale University, 17 Hillhouse Ave, New Haven, Connecticut 06511, United States

This file includes:

Experimental Section

Supplementary Figures S1-S15

Supplementary Tables S1-S3

References for SI Citations 


\section{Experimental Section}

Text S1. Detection of Organic Pollutants and Intermediates. HPLC (Agilent Technologies 1260 Infinity) was employed for detecting the concentration of organics, and the stationary phase was a $5 \mu \mathrm{m}$ Eclipse XDB-C18 column $(4.6 \mathrm{~mm} \times 150 \mathrm{~mm})$. Detailed conditions for the detections are addressed in Table SI. Intermediates were detected by GC-MS (Agilent Technologies, 7200 Accurate-Mass Q-TOF, 7890B GC system). Dichloromethane was used for the abstraction of organics from the aqueous phase.

Table SI. Relevant parameters for HPLC

\begin{tabular}{cccc}
\hline $\begin{array}{c}\text { Organic } \\
\text { compound }\end{array}$ & $\begin{array}{c}\text { Wavelength } \\
(\mathrm{nm})\end{array}$ & Mobile phase & $\begin{array}{c}\text { Flow rate } \\
\left(\mathrm{mL} \mathrm{min}^{-1}\right)\end{array}$ \\
\hline DCP & 275 & methanol (70\%) and 0.1\% phosphoric acid solution (30\%) & 1.0 \\
BPA & 230 & acetonitrile (50\%) and 0.1\% phosphoric acid solution (50\%) & 1.0 \\
4-CP & 225 & acetonitrile (45\%) and 0.1\% phosphoric acid solution (55\%) & 2.0 \\
TCP & 205 & acetonitrile (60\%) and 0.1\% phosphoric acid solution (40\%) & 2.0 \\
EE & 205 & acetonitrile (55\%) and 0.1\% phosphoric acid solution (45\%) & 2.0 \\
DMA & 254 & acetonitrile (80\%) and 0.1\% phosphoric acid solution (20\%) & 1.0 \\
4-CA & 254 & acetonitrile (40\%) and sodium citrate buffer (60\%) & 2.0 \\
NPA & 230 & acetonitrile (60\%) and 0.1\% phosphoric acid solution (40\%) & 1.0 \\
\hline
\end{tabular}

Text S2. Retention Time in Membranes. The retention time $\left(t_{R}, \mathrm{~s}\right)$ can be calculated by Equation S1,

$$
t_{R}=\frac{V_{I}}{Q} \cdot \frac{d_{O}^{2}}{d_{m}^{2}}
$$

where $V_{I}$ is the inner volume of membranes, $\mathrm{m}^{3}$, which can be determined by a "water-filling" method with details described in our previous work. ${ }^{1}$ The $V_{I}$ data for $\mathrm{Mn}_{3} \mathrm{O}_{4}$-AAO series, i.e., $\mathrm{NR}_{<20}, \mathrm{NR}_{40-70}$, and $\mathrm{NR}_{200}$ 300 , were about $0.76 \times 10^{-8}, 1.08 \times 10^{-8}$, and $1.56 \times 10^{-8} \mathrm{~m}^{3}$, respectively (Table $\mathrm{S} 1$ ), and for $\mathrm{Mn}_{3} \mathrm{O}_{4}-\mathrm{CM}$ was about $3.5 \times 10^{-7} \mathrm{~m}^{3} ; Q$ is the flux, $\mathrm{m}^{3} \mathrm{~s}^{-1} ; \mathrm{d}_{O}$ is the diameter of the O-ring rubber that represents the effective diameter for flow-through reaction, specifically $0.015 \mathrm{~m}$ for $\mathrm{Mn}_{3} \mathrm{O}_{4}-\mathrm{AAO}$ and $0.025 \mathrm{~m}$ for $\mathrm{Mn}_{3} \mathrm{O}_{4}-\mathrm{CM} ; \mathrm{d}_{m}$ is the diameter of membrane, specifically $0.024 \mathrm{~m}$ for $\mathrm{Mn}_{3} \mathrm{O}_{4}-\mathrm{AAO}$ and $0.027 \mathrm{~m}$ for $\mathrm{Mn}_{3} \mathrm{O}_{4}-\mathrm{CM}$. Different $t_{R}$ values versus different water fluxes within our tested range are shown in Figure $\mathrm{S} 12$ (for $\mathrm{Mn}_{3} \mathrm{O}_{4}-\mathrm{AAO}$ series) and Figure $\mathrm{S} 14$ (for $\mathrm{Mn}_{3} \mathrm{O}_{4}-\mathrm{CM}$ ), respectively.

Text S3. SVR-Normalized Kinetics. The SVR can be calculated according to Equation S2.

$$
\mathrm{SVR}=\frac{S_{B E T, M n_{3} O_{4}} \times W_{M n_{3} O_{4}}}{V_{I}}
$$

where $S_{B E T, M n_{3} O_{4}}$ is the specific surface area of the synthesized $\mathrm{Mn}_{3} \mathrm{O}_{4}, 61.2 \mathrm{~m}^{2} \mathrm{~g}^{-1}$, according to the nitrogen adsorption-desorption isotherms (Figure S15); $W_{M n_{3} O_{4}}$ is the amount of $\mathrm{Mn}_{3} \mathrm{O}_{4}$ loaded on the AAO template, $\mathrm{g} ; V_{I}$ is the internal volume of $\mathrm{NRs}, \mathrm{m}^{3}$. Relevant data for calculation of the SVR are listed in Table S1.

Then, we can get the SVR-normalized enhancement factor $\left(E_{S V R}\right.$, dimensionless) according to the pseudo-first order kinetic constants obtained by the NRs $\left(k_{o b s, N R}\right)$ and batch reactor $\left(k_{o b s, b a t c h}\right)$, as shown in Equation S3. 


$$
E_{S V R}=\frac{k_{o b s, N R}}{S V R_{N R}} / \frac{k_{o b s, \text { batch }}}{S V R_{\text {batch }}}
$$

Text S4. Calculation of $\mathbf{p H} \mathbf{H}_{\text {pore }}$. The surface of manganese(III/IV) oxide minerals are negatively charged at neutral $\mathrm{pH}$ (points of zero charge $<4.6^{2}$ ). The surface charge density can be converted to volumetric charge density $\left(\mathrm{mol} \mathrm{m}^{-3}\right), X$, by

$$
X=\frac{2 \sigma}{F H}
$$

where $\sigma$ is the surface charge density, $0.8 \mathrm{C} \mathrm{m}^{-2}$ (ref. 3$)^{3} ; F$ is the Faraday constant, $\mathrm{C} \mathrm{mol}{ }^{-1} ; H$ is the characteristic size, $\mathrm{m}$. Specifically, for a cylindrical pore, the characteristic size is the pore radius. Inside the nanopore, the volumetric charge density is balanced by the ionic charge density, which is the difference between the cation $\left(c_{+}\right)$and the anion $\left(c_{-}\right)$concentrations:

$$
c_{+}-c_{-}+X=0
$$

The concentrations of cations and anions inside the pore is related to the salt concentration outside the nanopore and the Donnan potential at the solution-pore interface. Assuming only monovalent salt is present, such expressions can be written as

$$
\begin{gathered}
c_{+}=c_{S} \exp \left(-\Delta \varphi_{D}\right) \\
c_{-}=c_{S} \exp \left(\Delta \varphi_{D}\right)
\end{gathered}
$$

where $c_{S}$ is the solution salt concentration outside the nanopore (i.e., $20 \mathrm{mM}$ monovalent salt); $\Delta \varphi_{D}$ is the Donnan potential at the solution-pore interface. Specifically, in our case, $\Delta \varphi_{D}$ is negative because of the negatively charged pore surface. Accordingly, the proton concentration inside the nanopore can be calculated based on the Donnan potential as

$$
c_{H^{+}}=c_{H^{+}, S} \exp \left(-\Delta \varphi_{D}\right)
$$

where $c_{H^{+}}$and $c_{H^{+}, S}$ are the proton concentrations of the pore and the bulk solution, respectively.

Text S5. Membrane operation cost. Note that there was no addition of chemicals during the membrane reaction. The cost for $\mathrm{Mn}_{3} \mathrm{O}_{4}-\mathrm{CM}$ membrane $\left(C_{m}, \mathrm{kWh} \mathrm{m}^{-3}\right)$ can be determined by the Equation $\mathrm{S} 8$,

$$
C_{m}=\frac{P \cdot V}{3600}
$$

where $P$ is the transmembrane pressure, about $27.56 \mathrm{kPa}$ for $20 \mathrm{LMH} ; V$ is a unit water volume, $1 \mathrm{~m}^{3}$. 


\section{Supplementary Figures}
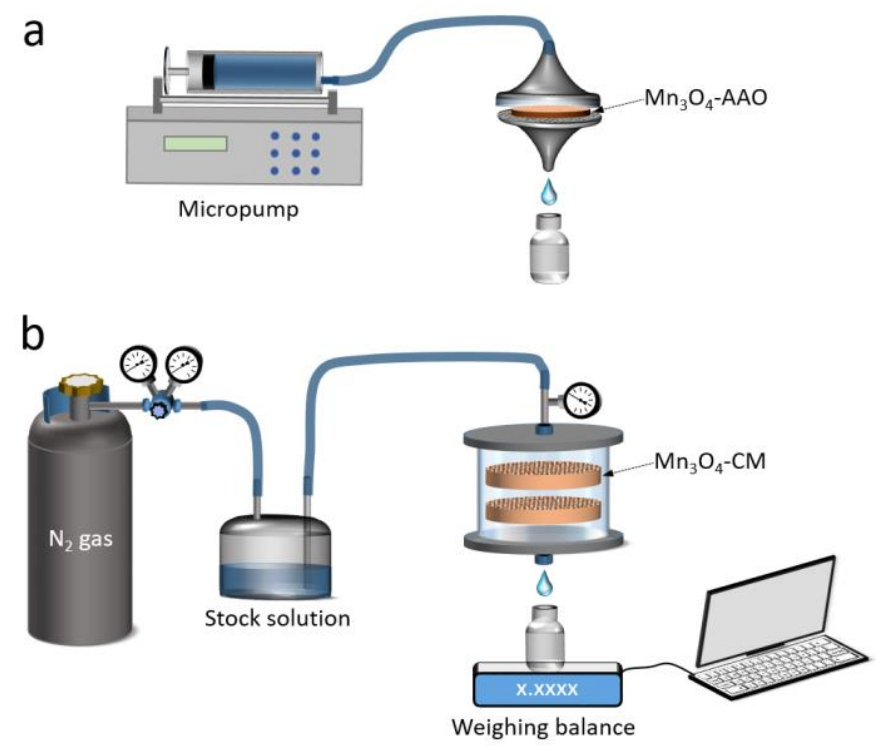

Figure S1. Schematic illustration of the setups for the flow-through reaction tests on (a) $\mathrm{Mn}_{3} \mathrm{O}_{4}-\mathrm{AAO}$ and (b) $\mathrm{Mn}_{3} \mathrm{O}_{4}-\mathrm{CM}$, respectively.
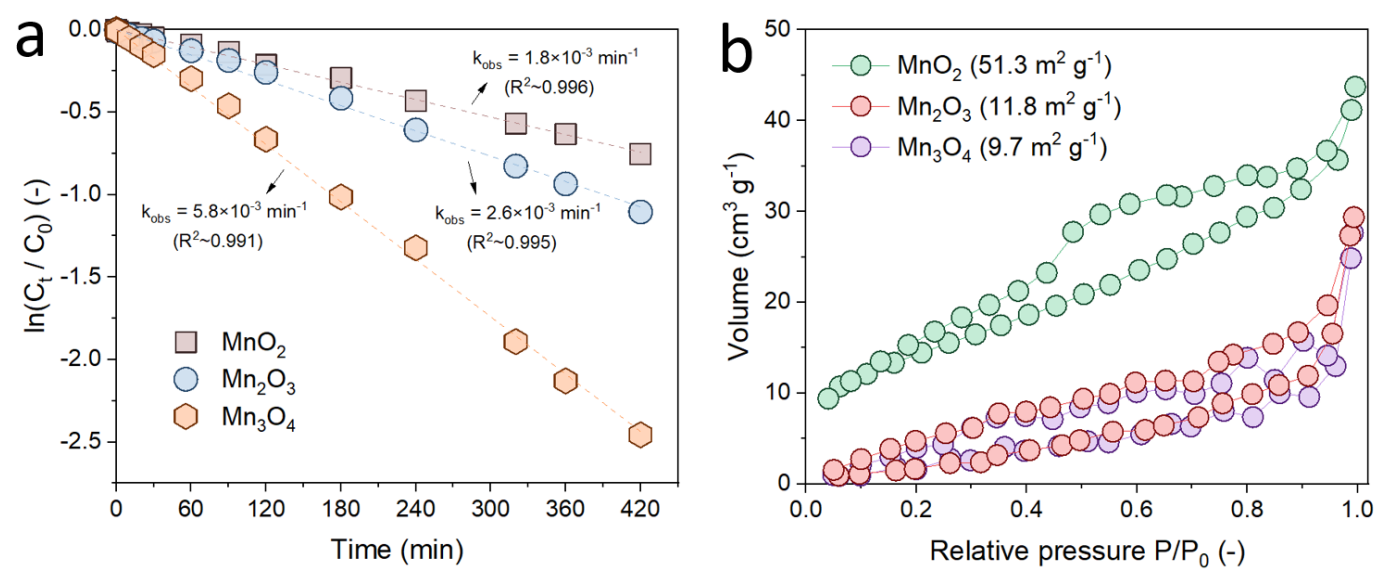

Figure S2. (a) Linear regression of the kinetics data for DCP oxidation by $\mathrm{MnO}_{2}, \mathrm{Mn}_{2} \mathrm{O}_{3}$, and $\mathrm{Mn}_{3} \mathrm{O}_{4}$, respectively. (b) The nitrogen adsorption/desorption isotherms for $\mathrm{MnO}_{2}, \mathrm{Mn}_{2} \mathrm{O}_{3}$, and $\mathrm{Mn}_{3} \mathrm{O}_{4}$, respectively. 


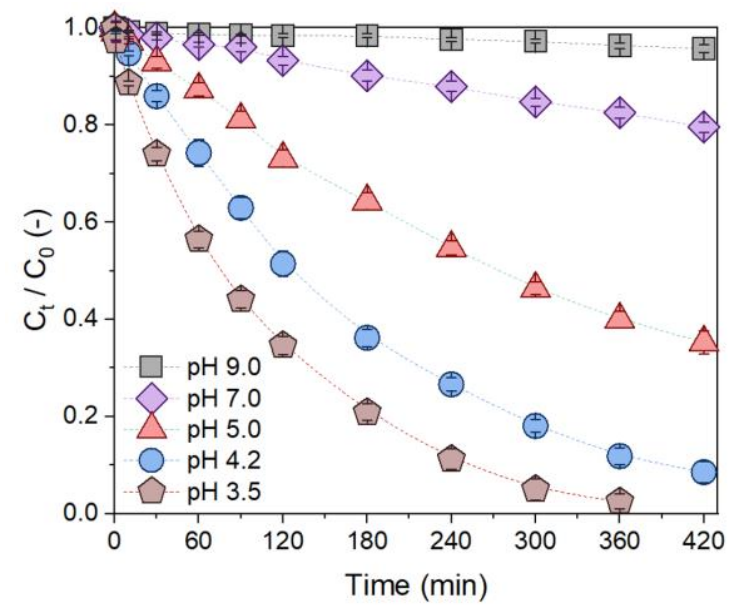

Figure S3. $\mathrm{Mn}_{3} \mathrm{O}_{4}$-catalyzed oxidation of DCP at different solution pHs. Conditions: initial organic concentration, $10 \mu \mathrm{M}$; solid load, $1 \mathrm{~g} \mathrm{~L}^{-1}$. Error bars represent the data from triplicate tests.
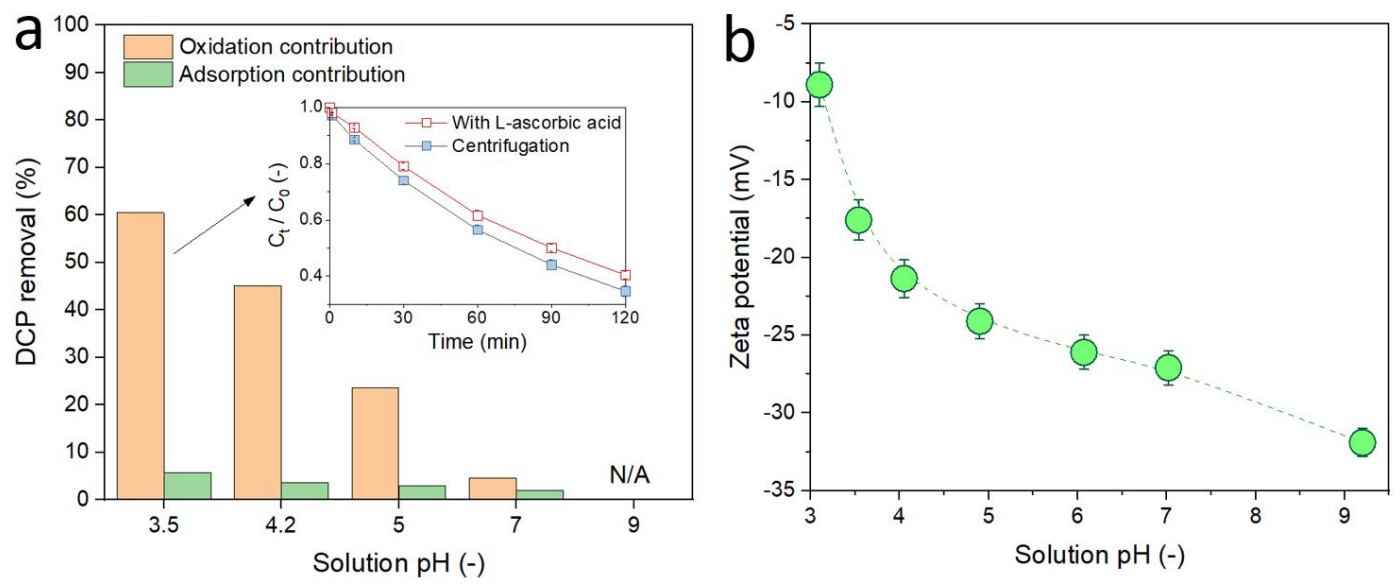

Figure S4. (a) pH effect on the percentage of oxidized and adsorbed DCP functionalized by $\mathrm{Mn}_{3} \mathrm{O}_{4}$ after 2hours of reaction time. Inset figure: the time-dependent concentration profiles with L-ascorbic acid and centrifugation treatment, respectively. Conditions: initial DCP concentration, $10 \mu \mathrm{M}$; solid load, $1 \mathrm{~g} \mathrm{~L}^{-1}$; $\mathrm{pH}$, 4.2. (b) Zeta potentials of $\mathrm{Mn}_{3} \mathrm{O}_{4}$ nanoparticles versus solution $\mathrm{pH}$. Error bars represent the data from triplicate tests.

L-ascorbic acid can rapidly reduce $\mathrm{Mn}_{3} \mathrm{O}_{4}$ to $\mathrm{Mn}^{2+}$ ions and release the adsorbed organic molecules back into the aqueous phase. ${ }^{4,5}$ After the samples were withdrawn from the reactor, we performed two different treatments: (i) immediately add L-ascorbic acid in excess $(0.1 \mathrm{M})$ to quench the oxidation reaction at the catalyst surface and dissolve the solid phase to completely release the adsorbed DCP back into the aqueous phase, so that the reduced DCP concentration can be attributed solely to the oxidation reaction; (ii) the reaction samples were centrifuged immediately to remove the solid phase, so that the reduced DCP concentration in the aqueous phase was caused by both surface-mediated oxidation and adsorption. This can explain why the time-dependent DCP concentrations after the centrifugation treatment (ii) were always lower than the L-ascorbic treatment (i), due to the adsorption effect, though not by much (Figure S4a inset). Then we quantified the adsorption contribution as a function of solution $\mathrm{pH}$ at a fixed time of 2 hours after the addition of $\mathrm{Mn}_{3} \mathrm{O}_{4}$ (Figure $\mathrm{S} 4 \mathrm{a}$ ). 

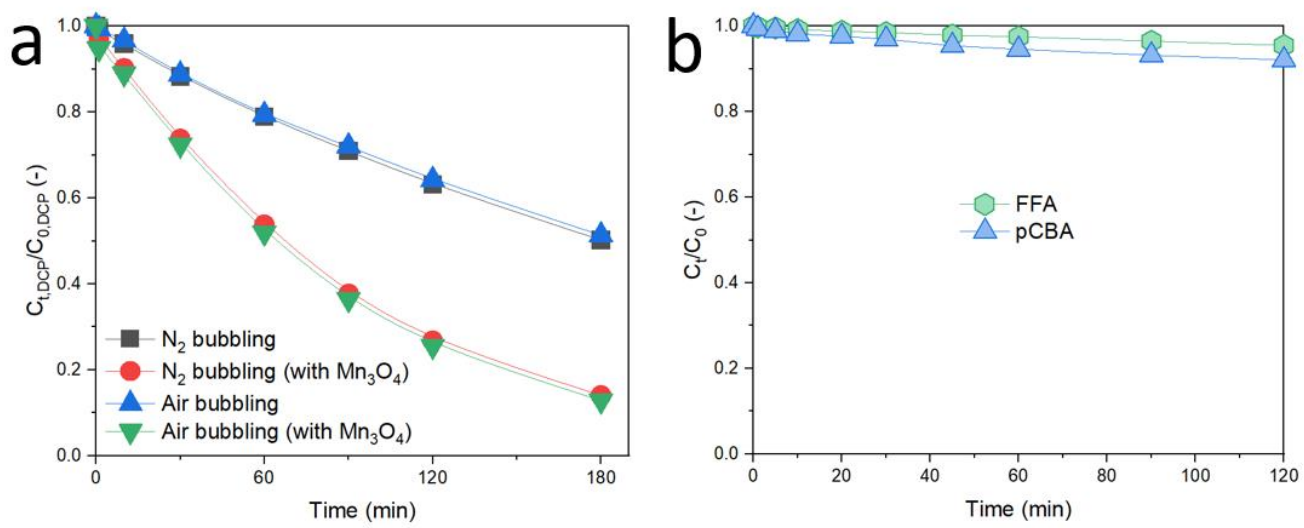

Figure S5. (a) Effect of dissolved oxygen on $\mathrm{Mn}_{3} \mathrm{O}_{4}$-catalyzed DCP degradation. Conditions: initial DCP concentration, $20 \mu \mathrm{M}$; solid load, $1 \mathrm{~g} \mathrm{~L}^{-1}$; $\mathrm{pH}$, 4.2. (b) Normalized concentration of FFA (singlet oxygen probe) and $p$ CBA (hydroxyl radical probe) versus time in the presence of $\mathrm{Mn}_{3} \mathrm{O}_{4}$. Conditions: organic concentration, $20 \mu \mathrm{M}$; solid load, $1 \mathrm{~g} \mathrm{~L}^{-1}$; $\mathrm{pH}, 4.2$.

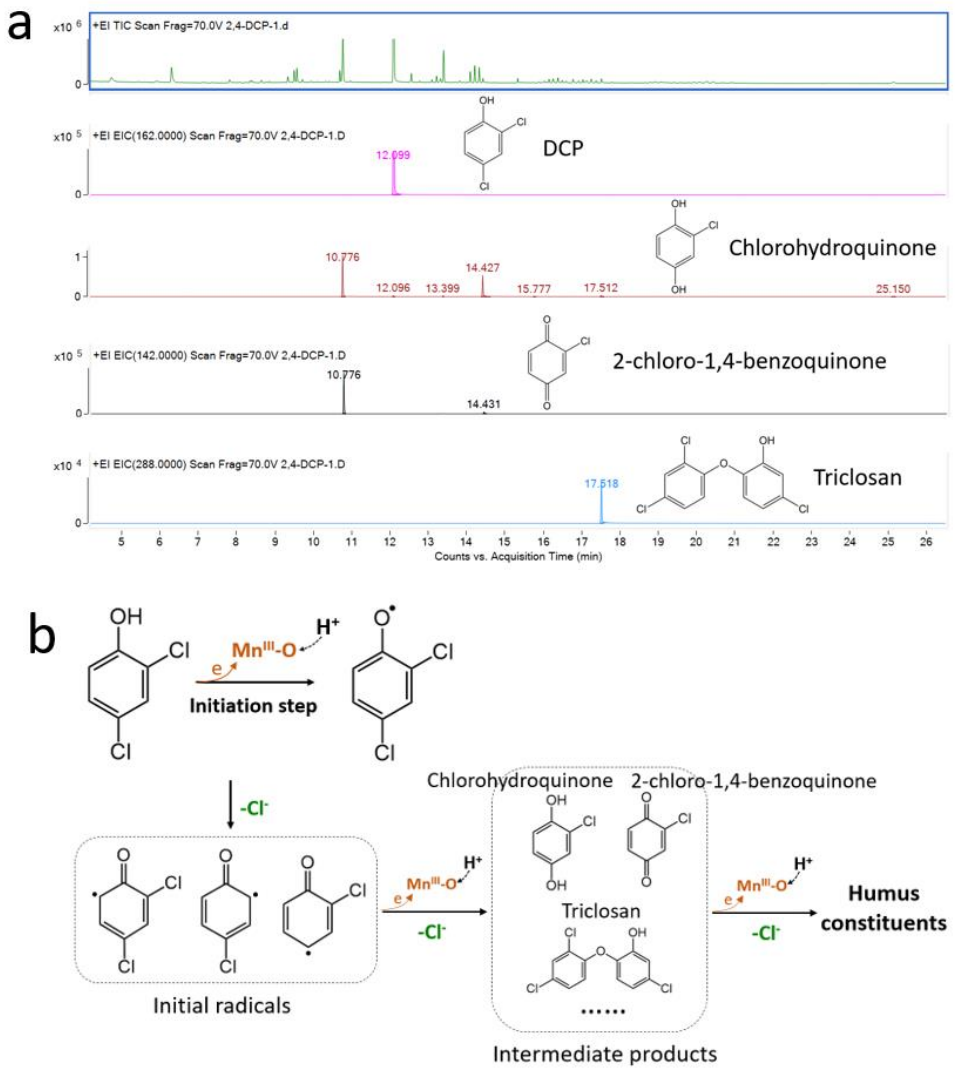

Figure S6. (a) GC-MS spectra of the solution after 2-hours of reaction time. (b) Schematic illustration of $\mathrm{Mn}_{3} \mathrm{O}_{4}$-catalyzed oxidation of DCP and the oligomerization process. Unpaired phenolic radicals on oxygen were first formed during the initiation concerted proton-electron transfer step, ${ }^{6,7}$ and quickly stabilized with resonance structures with the unpaired electrons delocalized to the ortho and para positions of the aromatic moiety. This stimulated complex coupling and oligomerization between radicals and molecules that is central to natural humification process. 


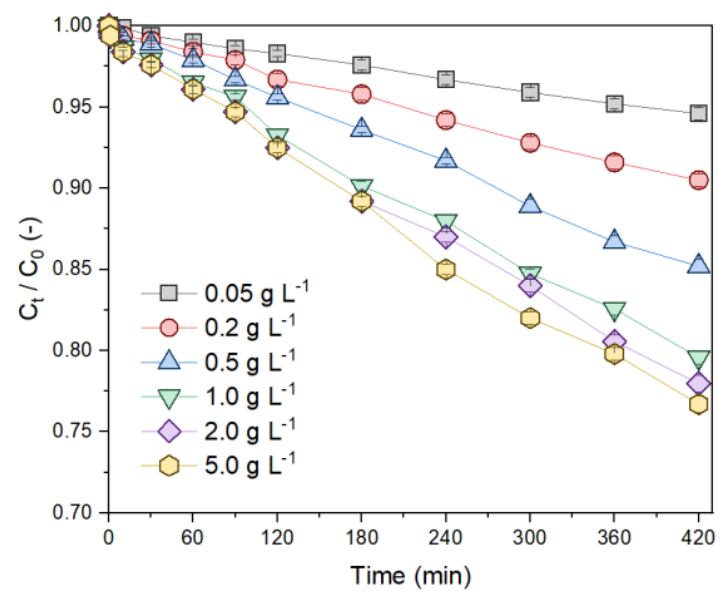

Figure S7. Normalized concentration of DCP versus time during batch-mode reaction using $\mathrm{Mn}_{3} \mathrm{O}_{4}$ nanoparticles. Conditions: initial organic concentration, $10 \mu \mathrm{M} ; \mathrm{pH}, 7.0$. Error bars represent the data from triplicate tests.
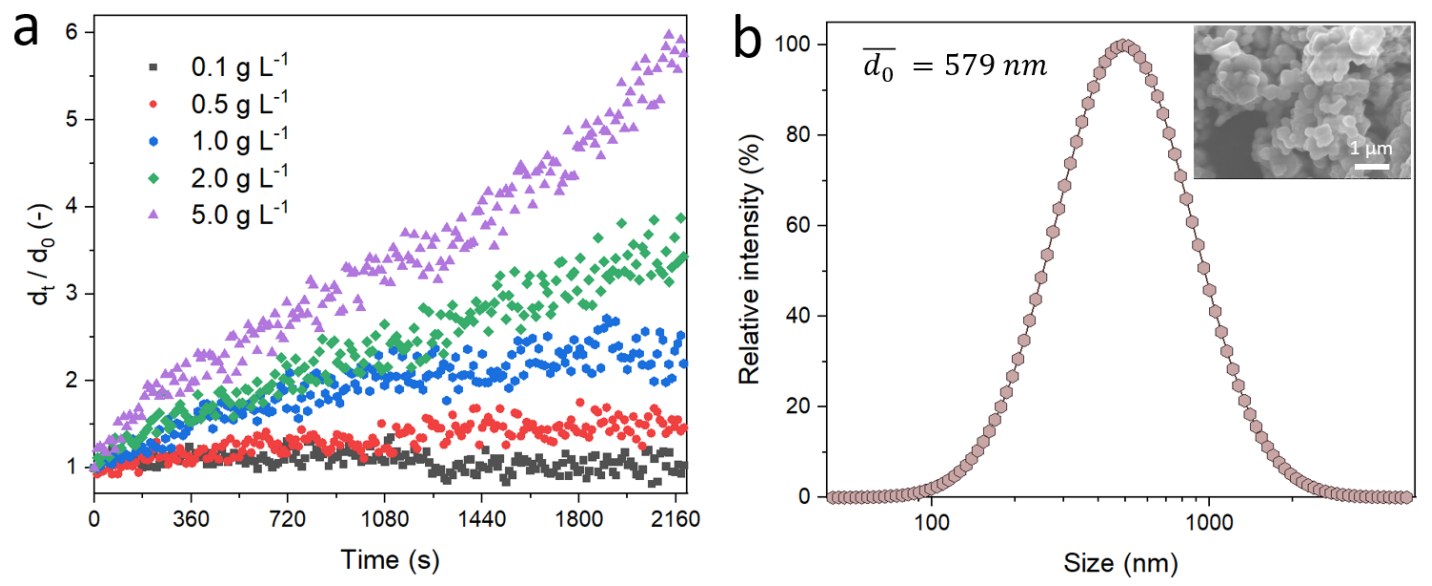

Figure S8. (a) Time-resolved dynamic light scattering (DLS) measurements at different particle concentrations. The DLS signal was acquired every $11 \mathrm{~s}$ for each of the tested concentration. (b) The particle size distribution (the tested concentration was reduced to $0.02 \mathrm{~g} \mathrm{~L}^{-1}$ to avoid aggregation). Inset figure is the SEM image of commercial $\mathrm{Mn}_{3} \mathrm{O}_{4}$ particles. 


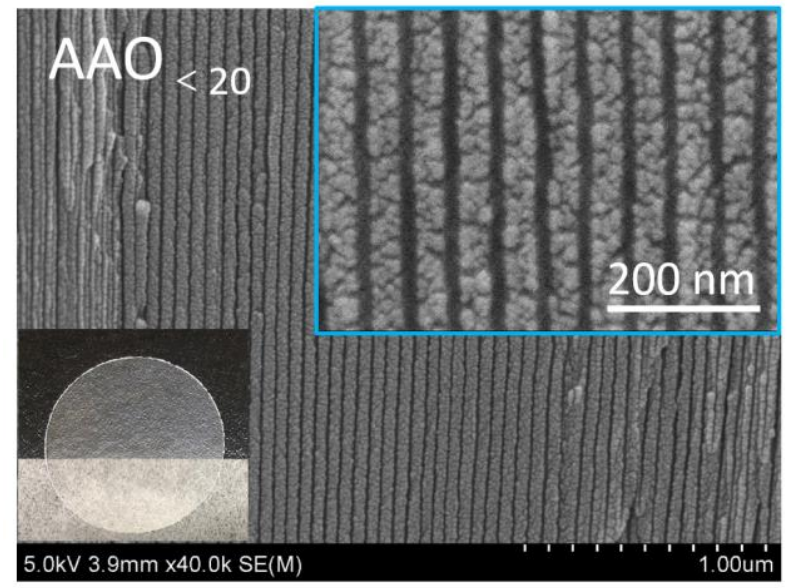

Figure S9. SEM images of AAO template with less than $20 \mathrm{~nm}$ channels. Inset figures respectively the magnified SEM image and the photo of $A A O<20$.

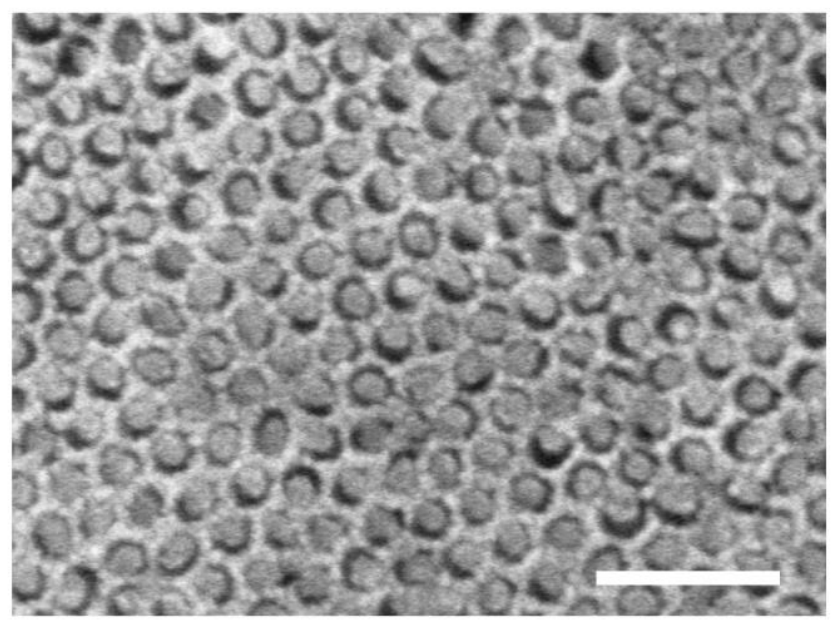

Figure S10. SEM image of the top-down view of the $\mathrm{NR}<20$ (scale bar, $100 \mathrm{~nm}$ ). After the surface polishing, only the $\mathrm{Mn}_{3} \mathrm{O}_{4}$ nanoparticles grown inside the channels were left for further reaction tests. 

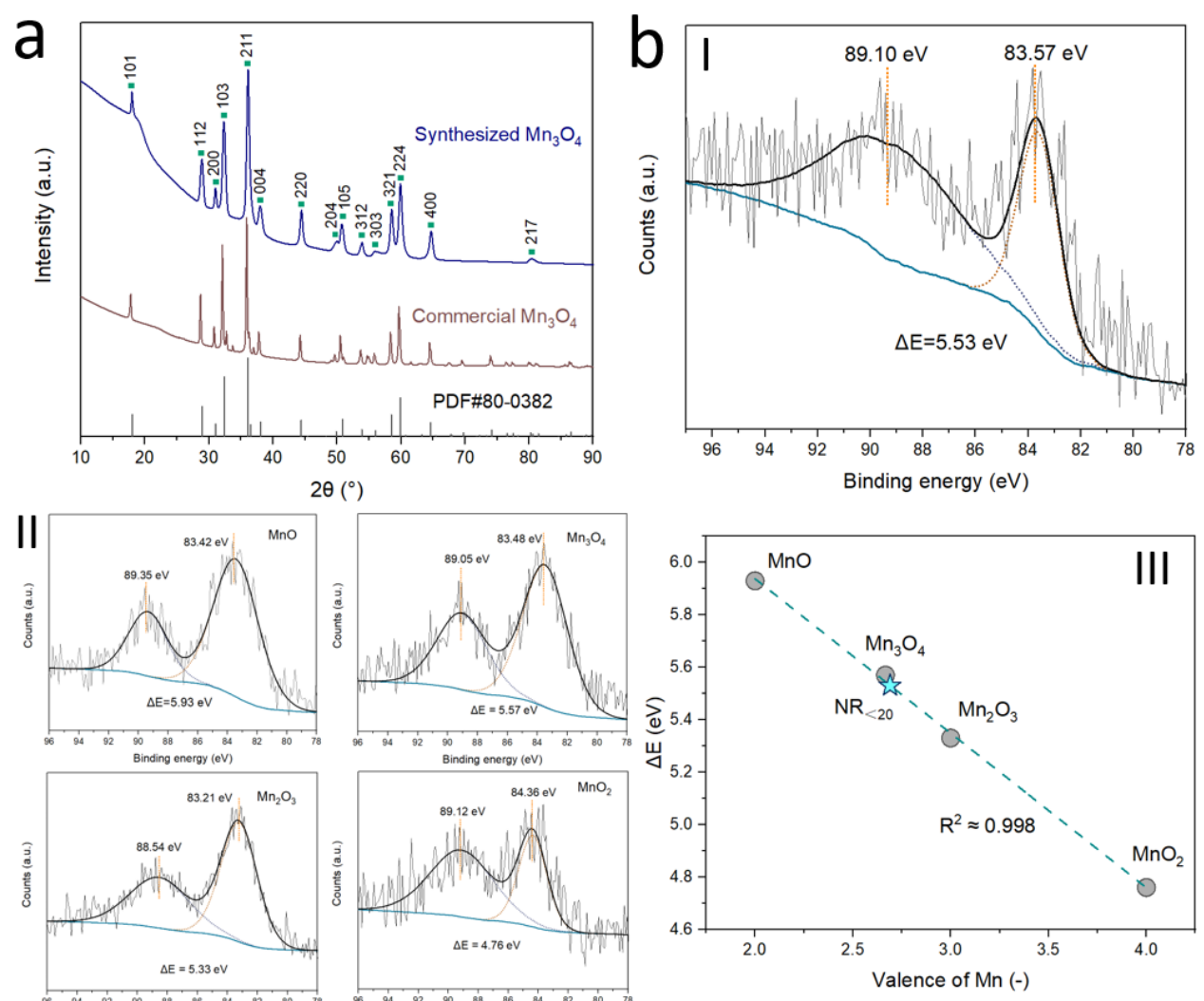

Figure S11. (a) XRD diffraction patterns of $\mathrm{Mn}_{3} \mathrm{O}_{4}$ synthesized by a solvothermal method and commercial $\mathrm{Mn}_{3} \mathrm{O}_{4}$ powder. (b) $\mathrm{Mn3s}$ XPS spectra of $\mathrm{Mn}_{3} \mathrm{O}_{4}$ in $\mathrm{AAO}\left(\mathrm{NR}_{<20}\right.$ as an example, figure I) and commercial $\mathrm{MnO}, \mathrm{Mn}_{2} \mathrm{O}_{3}, \mathrm{Mn}_{3} \mathrm{O}_{4}$, and $\mathrm{MnO}_{2}$ (figure II). The splitting width of $5.53 \mathrm{eV}$ for the $\mathrm{Mn} 3 \mathrm{~s}$ signal fits well with the commercial $\mathrm{Mn}_{3} \mathrm{O}_{4}$ as the benchmark (figure III), indicating the successful synthesis of $\mathrm{Mn}_{3} \mathrm{O}_{4}$ inside the AAO template.

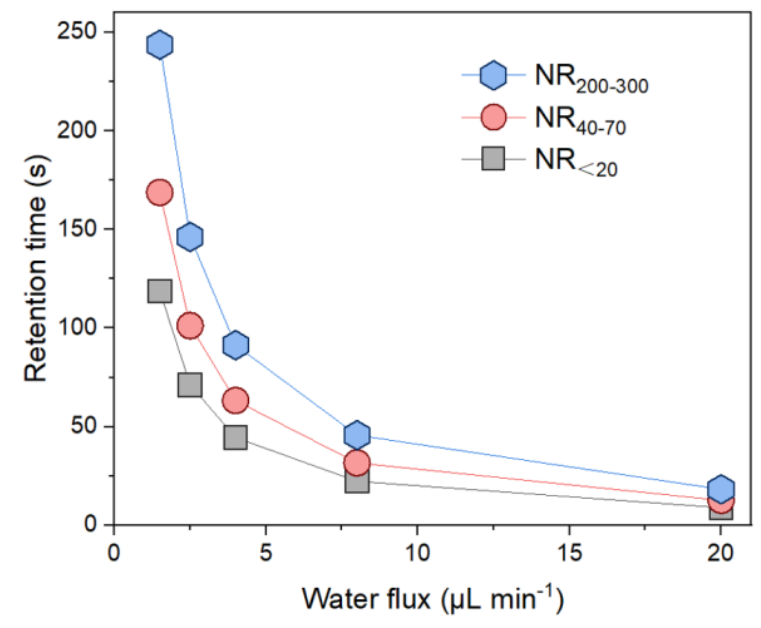

Figure S12. Variation of retention time as a function of water fluxes applied for the NRs series. 

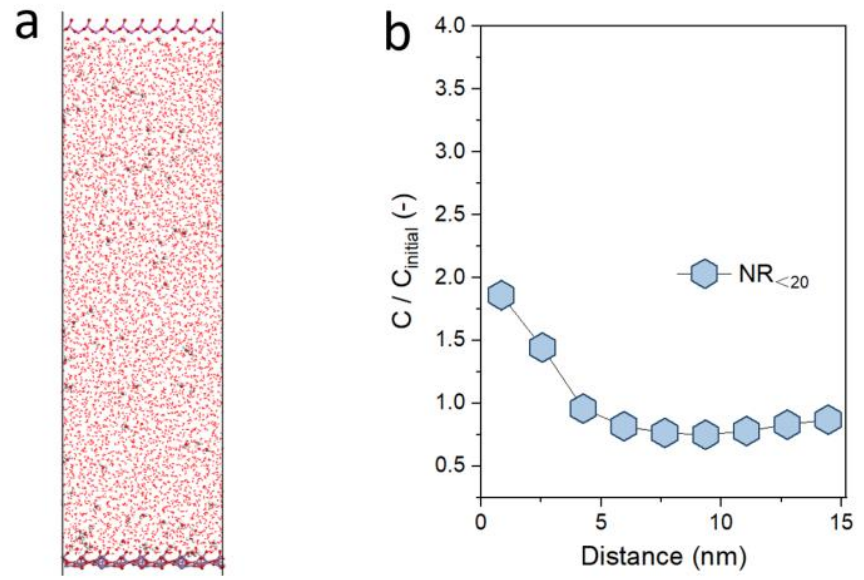

Figure S13. MD simulation snapshot of $\mathrm{H}_{3} \mathrm{O}^{+}$confined in $\mathrm{AAO}$ channels with a distance of $15 \mathrm{~nm}$ from $\mathrm{Al}_{2} \mathrm{O}_{3}$ to $\mathrm{Mn}_{3} \mathrm{O}_{4}$ surface.

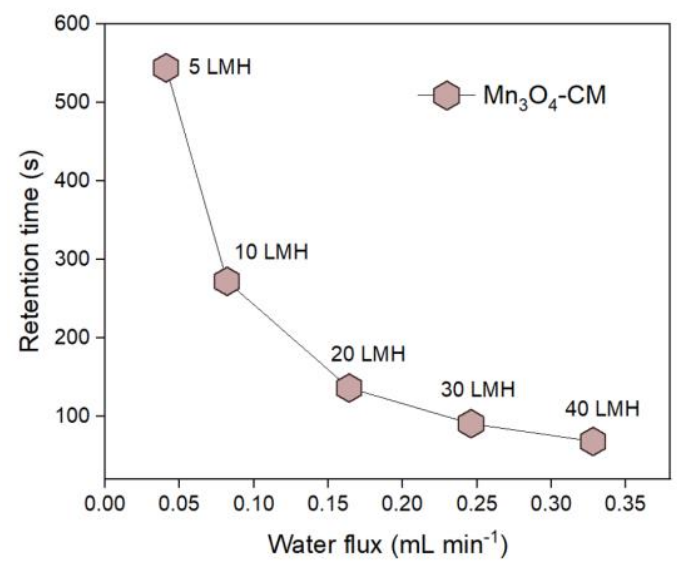

Figure S14. Variation of retention time as a function of water fluxes applied for the $\mathrm{Mn}_{3} \mathrm{O}_{4}-\mathrm{CM}$ membrane.

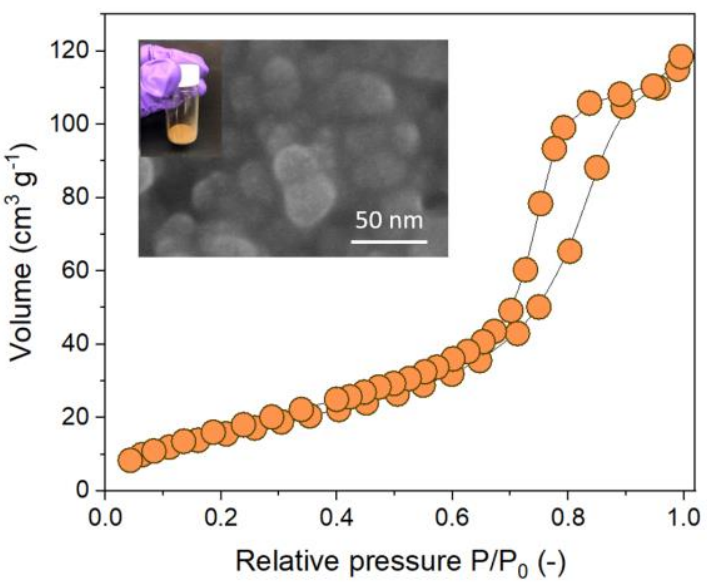

Figure S15. The nitrogen adsorption/desorption isotherm for the as-synthesized $\mathrm{Mn}_{3} \mathrm{O}_{4}$ nanoparticles. Inset figure is the SEM image of $\mathrm{Mn}_{3} \mathrm{O}_{4}$ nanoparticles that are within the range of 10-30 nm, much smaller than the commercial $\mathrm{Mn}_{3} \mathrm{O}_{4}$ counterpart (Figure $\mathrm{S} 8 \mathrm{~b}$ ). 


\section{Supplementary Tables}

Table S1. Basic parameters for determination of SVR in NRs

\begin{tabular}{ccccc}
\hline System & $W_{M n_{3} \mathrm{O}_{4}{ }^{\mathrm{a}}(\mathrm{mg})}$ & Pore size $(\mathrm{nm})$ & $\begin{array}{c}\text { Inner volume }\left(V_{I}\right)^{\mathrm{b}} \\
\left(\times 10^{-8} \mathrm{~m}^{3}\right)\end{array}$ & $\begin{array}{c}\text { SVR } \\
\left(\times 10^{6} \mathrm{~m}^{2} \mathrm{~m}^{-3}\right)\end{array}$ \\
\hline $\mathrm{NR}_{<20}$ & $1.1( \pm 13 \%)$ & $3-5$ & $0.84( \pm 6.3 \%)$ & 8.04 \\
$\mathrm{NR}_{40-70}$ & $0.7( \pm 17 \%)$ & $20-40$ & $1.08( \pm 7.6 \%)$ & 3.96 \\
$\mathrm{NR}_{200-300}$ & $0.5( \pm 15 \%)$ & $200-300$ & $1.56( \pm 6.1 \%)$ & 1.94 \\
\hline
\end{tabular}

${ }^{a}$ Data for the loading of $\mathrm{Mn}_{3} \mathrm{O}_{4}$ on $\mathrm{AAO}$ is the average value of triplicate measurements.

${ }^{\mathrm{b}}$ Data for the pore volume is the average value of triplicate measurements.

Table S2. The quality of simulated contaminated ground water.

\begin{tabular}{cc}
\hline General Parameters ${ }^{\mathrm{a}}$ & Specification \\
\hline Water source & DI (conductivity $\left.<1 \mu \mathrm{S} \mathrm{cm}^{-1}\right)$ \\
Adjusted $\mathrm{pH}$ & 7.0 \\
Temperature & $21-22^{\circ} \mathrm{C}$ \\
\hline Constituents & Concentration $(\mathbf{m M})$ \\
\hline Organic compound & 0.005 \\
Bicarbonate $\left(\mathrm{HCO}_{3}{ }^{-}\right)$ & 3.0 \\
Calcium $\left(\mathrm{Ca}^{2+}\right)$ & 1.0 \\
Chloride $\left(\mathrm{Cl}^{-}\right)$ & 2.0 \\
Fluoride $\left(\mathrm{F}^{-}\right)$ & 0.053 \\
Magnesium $\left(\mathrm{Mg}^{2+}\right)$ & 0.5 \\
Nitrate $\left(\mathrm{NO}_{3}^{-}\right)$ & 0.14 \\
Phosphate $\left(\mathrm{PO}_{4}{ }^{3-}\right)$ & 0.0013 \\
Silica $\left(\mathrm{SiO}_{2}\right)$ & 0.33 \\
Sodium $\left(\mathrm{Na}^{+}\right)$ & 3.86 \\
Sulfate $\left(\mathrm{SO}_{4}{ }^{2-}\right)$ & 0.50 \\
Ionic strength & 8.5 \\
\hline
\end{tabular}


Table S3. Chemicals used as model organic contaminants.

\begin{tabular}{|c|c|c|c|c|c|}
\hline Compound & CAS No. & Structure $^{\mathrm{a}}$ & Formula & Industrial use & Health risk \\
\hline DCP & $120-83-2$ & & $\mathrm{C}_{6} \mathrm{H}_{4} \mathrm{Cl}_{2} \mathrm{O}$ & $\begin{array}{c}\text { Herbicide/preservative/ } \\
\text { disinfectant manufacturing }\end{array}$ & $\begin{array}{l}\text { Mutagenicity/genotoxicity/ } \\
\text { carcinogenicity }\end{array}$ \\
\hline BPA & $80-05-7$ & & $\mathrm{C}_{15} \mathrm{H}_{16} \mathrm{O}_{2}$ & $\begin{array}{l}\text { Producing polycarbonate } \\
\text { plastic and epoxy resins }\end{array}$ & $\begin{array}{l}\text { Reproductive/metabolic/ } \\
\text { neurological function } \\
\text { disruptor }\end{array}$ \\
\hline $4-\mathrm{CP}$ & $106-48-9$ & & $\mathrm{C}_{6} \mathrm{H}_{5} \mathrm{ClO}$ & $\begin{array}{c}\text { Agricultural } \\
\text { chemicals/dyes/drugs } \\
\text { manufacturing }\end{array}$ & $\begin{array}{c}\text { Genotoxicity/mutagenicity } \\
\text { /carcinogenicity }\end{array}$ \\
\hline TCP & $88-06-2$ & & $\mathrm{C}_{6} \mathrm{H}_{3} \mathrm{Cl}_{3} \mathrm{O}$ & $\begin{array}{l}\text { Insecticide/fungicide/ } \\
\text { herbicide/bactericide/ } \\
\text { germicide }\end{array}$ & $\begin{array}{c}\text { Liver/hematologic system; } \\
\text { carcinogen }\end{array}$ \\
\hline $\mathrm{EE}$ & $57-63-6$ & & $\mathrm{C}_{20} \mathrm{H}_{24} \mathrm{O}_{2}$ & $\begin{array}{l}\text { Medication as } \\
\text { contraceptive }\end{array}$ & Endocrine disruptor \\
\hline DMA & $121-69-7$ & & $\mathrm{C}_{8} \mathrm{H}_{11} \mathrm{~N}$ & $\begin{array}{c}\text { Dyes/pigments/ } \\
\text { pharmaceuticals } \\
\text { manufacturing }\end{array}$ & $\begin{array}{l}\text { Central nervous system/ } \\
\text { circulatory system/ } \\
\text { blood/liver damage }\end{array}$ \\
\hline 4-CA & $106-47-8$ & & $\mathrm{C}_{6} \mathrm{H}_{6} \mathrm{NCl}$ & $\begin{array}{l}\text { Pesticide/drug/dye } \\
\text { manufacturing }\end{array}$ & $\begin{array}{c}\text { Blood/liver/kidney/ } \\
\text { nervous system damage; } \\
\text { carcinogen }\end{array}$ \\
\hline NPA & $134-32-7$ & & $\mathrm{C}_{10} \mathrm{H}_{9} \mathrm{~N}$ & Dye/rubber manufacturing & $\begin{array}{c}\text { Blood/respiratory system } \\
\text { damage; mutation }\end{array}$ \\
\hline
\end{tabular}

${ }^{a}$ The compound geometries were obtained using Chem3D software (ChemOffice Professional 18.0). Gray = carbon, red $=$ oxygen, white $=$ hydrogen, blue $=$ nitrogen, and green $=$ chloride .

\section{References}

(1) Zhang, S.; Sun, M.; Hedtke, T.; Deshmukh, A.; Zhou, X. C.; Weon, S.; Elimelech, M.; Kim, J. H. Mechanism of Heterogeneous Fenton Reaction Kinetics Enhancement under Nanoscale Spatial Confinement. Environ. Sci. Technol. 2020, 54, 10868-10875.

(2) Husnain, S. M.; Asim, U.; Yaqub, A.; Shahzad, F.; Abbas, N. Recent Trends of $\mathrm{MnO}_{2}$-Derived Adsorbents for Water Treatment: a Review. New J. Chem. 2020, 44, 6096-6120.

(3) MURRAY, J. W. The Surface Chemistry of Hydrous Manganese Dioxide. J. Colloid Interf. Sci. 1973, 46, 357-371.

(4) Ulrich, H. J.; Stone, A. T. Oxidation of Chlorophenols Adsorbed to Manganese Oxide Surfaces. Environ. Sci. Technol. 1989, 23, 421-428.

(5) Zhang, H. C.; Huang, C. H. Oxidative Transformation of Triclosan and Chlorophene by Manganese Oxides. Environ. Sci. Technol. 2003, 37, 2421-2430.

(6) Stone, A. T. Reductive Dissolution of Manganese(III/IV) Oxides by Substituted Phenols. Environ. Sci. Technol. 1987, 21, 979-988.

(7) Parada, G. A.; Goldsmith, Z. K.; Kolmar, S.; Rimgard, B. P.; Mercado, B. Q.; Hammarstrom, L.; Hammes-Schiffer, S.; Mayer, J. M. Concerted Proton-Electron Transfer Reactions in the Marcus Inverted Region. Science 2019, 364, 471-475. 